Research article

\title{
A high-performance doped photocatalysts for inactivation of total coliforms in superficial waters using different sources of radiation
}

\author{
Elis Marina Turini Claro a, b, Ederio Dino Bidoia ${ }^{\text {b, }}{ }^{\text {, }}$, Peterson Bueno de Moraes ${ }^{a}$ \\ ${ }^{a}$ University of Campinas (UNICAMP), Department of Technologies for Environmental Sanitation, Faculty of Technology (FT), R. Paschoal Marmo, 1888, Nova \\ Itália, 13484-332, Limeira, SP, Brazil \\ b São Paulo State University (UNESP), Department of Biochemistry and Microbiology, Av. 24 A, 1515, Bela Vista, 13506-900, Rio Claro, SP, Brazil
}

\section{A R T I C L E I N F O}

\section{Article history:}

Received 29 September 2015

Received in revised form

4 April 2016

Accepted 12 April 2016

Available online 22 April 2016

\section{Keywords:}

Superficial water treatment

Heterogeneous photocatalysis

UV-A LED

Disinfection

Si-doped

$\mathrm{N}$-doped

\begin{abstract}
A B S T R A C T
Photocatalytic water treatment has a currently elevated electricity demand and maintenance costs, but the photocatalytic water treatment may also assist in overcoming the limitations and drawbacks of conventional water treatment processes. Among the Advanced Oxidation Processes, heterogeneous photocatalysis is one of the most widely and efficiently used processes to degrade and/or remove a wide range of polluting compounds. The goal of this work was to find out a highly efficient photocatalytic disinfection process in superficial water with different doped photocatalysts and using three sources of radiation: mercury vapor lamp, solar simulator and UV-A LED. Three doped photocatalysts were prepared, SiZnO, N-SiZnO and $\mathrm{F}-\mathrm{N}-\mathrm{SiZnO}$. The inactivation efficiency of each synthesized photocatalysts was compared to a $\mathrm{TiO}_{2} \mathrm{P} 25$ (Degussa ${ }^{\circledR}$ ) $0.5 \mathrm{~g} \mathrm{~L}^{-1}$ control. Photolysis inactivation efficiency was $85 \%$ with UV-A LED, which is considered very high, demanding low electricity consumption in the process, whereas mercury vapor lamp and solar simulator yielded $19 \%$ and $13 \%$ inactivation efficiency, respectively. The best conditions were found with photocatalysts SiZnO, F-N-SiZnO and N-SiZnO irradiated with UV-A LED, where efficiency exceeded $95 \%$ that matched inactivation of coliforms using the same irradiation and photocatalyst $\mathrm{TiO}_{2}$. All photocatalysts showed photocatalytic activity with all three radiation sources able to inactivate total coliforms from river water. The use of UV-A LED as the light source without photocatalyst is very promising, allowing the creation of cost-effective and highly efficient water treatment plants.
\end{abstract}

๑) 2016 Elsevier Ltd. All rights reserved.

\section{Introduction}

The use of chlorine as a disinfectant in water treatment facilities should be investigated. Recent studies have shown that chlorine is ineffective in eliminating epidemic agents such as Giardia sp and Cryptosporidium sp. Furthermore, the reaction between free residual chlorine compounds and natural organic acids, such as humic acids and fulvic acids (precursors) leads to the formation of several byproducts. Some of these compounds can cause potentially carcinogenic effects, as trihalomethanes and haloacetic acids are the main products formed (Zhang et al., 2010; Dyck et al., 2015; Wu et al., 2014).

\footnotetext{
* Corresponding author. São Paulo State University (UNESP), Department of Biochemistry and Microbiology, Av. 24 A, 1515, Bela Vista, 13506-900, Rio Claro, SP, Brazil.

E-mail addresses: ma_turini@hotmail.com (E.M.T. Claro), ederio@rc.unesp.br (E.D. Bidoia), peterson@ft.unicamp.br (P.B. de Moraes).
}

In that way, alternative processes for water disinfection, such as Advanced Oxidation Processes (AOPs) have received great attention due to their capacity to convert pollutants into harmless chemical species (Nickheslat et al., 2013). AOPs are oxidation processes in which hydroxyl radicals $\left(\mathrm{OH}^{\bullet}\right)$ are generated in sufficient quantities to serve as the main oxidizing agents (Lopes et al., 2012; Wang et al., 2014). Among the AOPs, heterogeneous photocatalysis has been widely studied and its principle involves the activation of a semiconductor by sunlight or artificial light (Lopes et al., 2011; Gulyas, 2014).

Titanium dioxide $\left(\mathrm{TiO}_{2}\right)$ materials of different types and forms have shown great potential as an ideal and a powerful semiconductor photocatalyst for various significant reactions due to their chemical stability, low cost, nontoxicity, and high reactivity (Lopes et al., 2011; Gulyas, 2014; Schneider et al., 2014; Wu et al., 2014; Wang et al., 2014). Other semiconductors have also been studied in photocatalysis, namely zinc oxide ( $\mathrm{ZnO})$, tungsten trioxide $\left(\mathrm{WO}_{3}\right)$, ferric oxide $\left(\mathrm{Fe}_{2} \mathrm{O}_{3}\right)$, zinc sulfide $(\mathrm{ZnS})$, etc. (Elamin 
and Elsanousi, 2013).

There are fundamental challenges for large-scale application of semiconductors as photocatalysts. Titanium dioxide is only activated under UV irradiation, specifically radiation with wavelengths below $388 \mathrm{~nm}$, and it can therefore not be excited using radiation in the visible region. Therefore, methods for semiconductor modifications include structural doping by using metals, metalloids, transition metals and no-metals (Lin et al., 2009; Estruga et al., 2010; Tan et al., 2011; Shi et al., 2011; Schneider et al., 2014). Other studies report co-doping of non-metallic and metallic elements such as Pt/N and Gd/N (Huang et al., 2007; Liu et al., 2011).

The inclusion of non-metallic doping species, (N, C, F and S) along with transition metals and metalloids ( $\mathrm{Si}$ ) improves overall photocatalysis efficiency under visible light spectrum (Yu et al., 2002; Umebayashi et al., 2003; Rengifo-Herrera et al., 2008; Estruga et al., 2010; Tan et al., 2011).

The combination of photocatalysts doped with transition metals and non-metallic species with ultraviolet light and visible-light has reportedly inactivated microorganisms, such as Escherichia coli (Rengifo-Herrera et al., 2008; Li et al., 2010; Rizzo et al., 2014), Staphylococcus aureus (Chen et al., 2012; Ananpattarachai and Boonto, 2015), Pseudomonas aeruginosa (Wu et al., 2009) and Bacillus subtilis (Wu et al., 2008).

This study aimed to propose a highly efficient photocatalytic disinfection process in superficial water with different doped photocatalysts by comparing three sources of radiation: mercury vapor lamp, solar simulator and UV-A LED.

\section{Material and methods}

\subsection{Doped photocatalysts}

The doped photocatalysts synthesis was performed as according to Li et al. (2010). Three doped photocatalysts were prepared: SiZnO, N-SiZnO and F-N-SiZnO.

In SiZnO synthesis, $12.0 \mathrm{~g}$ of zinc sulfate $\left(\mathrm{ZnSO}_{4}\right)$ and $12.0 \mathrm{~g}$ of silica were dissolved in $200 \mathrm{~mL}$ deionized water under rigorous stirring until complete dissolution. Then, the solution was sonicated in ultrasonic bath for $1 \mathrm{~h}$. The $\mathrm{pH}$ was adjusted to 7.2 with sodium hydroxide $(\mathrm{NaOH})$ to produce a white precipitate, which stood for $12 \mathrm{~h}$ protected from light. The precipitate was filtered through a $0.45 \mu \mathrm{m}$ cellulose membrane and it was washed with deionized water several times to remove the sulfate. Afterwards the sample was evaporated in an oven for $10 \mathrm{~h}$ at $60^{\circ} \mathrm{C}$ and calcined for $2 \mathrm{~h}$ at $300^{\circ} \mathrm{C}$. After calcination, the material was ground to obtain the finest powder possible.

The $\mathrm{N}-\mathrm{SiZnO}$ compound was prepared using the same procedure used for SiZnO, but with ammonium hydroxide $\left(\mathrm{NH}_{4} \mathrm{OH}\right)$ as a precipitator instead. In $\mathrm{F}-\mathrm{N}-\mathrm{SiZnO}$ preparation, $1.0 \mathrm{~g}$ of $\mathrm{N}-\mathrm{SiZnO}$ was mixed with $0.2 \mathrm{~g}$ of ammonium fluoride $\left(\mathrm{NH}_{4} \mathrm{~F}\right)$ with $4 \mathrm{~mL}$ of deionized water. The mixture was sonicated in an ultrasonic bath for $40 \mathrm{~min}$ and afterwards left $10 \mathrm{~h}$ protected from light. Then, the compound was evaporated in an oven for $60{ }^{\circ} \mathrm{C}$ for $12 \mathrm{~h}$ and calcined for $2 \mathrm{~h}$ at $300{ }^{\circ} \mathrm{C}$ to obtain $\mathrm{F}-\mathrm{N}-\mathrm{SiZnO}$. After calcination, the material was ground to obtain the finest powder possible.

For comparison purposes, a synthesized photocatalyst $\mathrm{TiO}_{2} \mathrm{P} 25$ (Degussa $^{\circledR}$ ) was used, since it is widely used in photocatalytic reactions.

\subsection{Description of the experimental apparatus}

Three different reactors were built to evaluate the photocatalytic activity under different radiation sources: mercury vapor lamp, UVA LED and solar simulator. These reactors were equipped with a beaker with a capacity of $450 \mathrm{~mL}$ and a magnetic stirrer that kept the sample in constant agitation. The temperature and the $\mathrm{pH}$ variation were monitored.

The first reactor used a mercury vapor lamp of $250 \mathrm{~W}\left(\right.$ Avant $\left.^{\circledR}\right)$, with a $365 \mathrm{~nm}$ wavelength, without the glass bulb. The temperature was maintained at $25{ }^{\circ} \mathrm{C}$. The lamp was positioned at $15 \mathrm{~cm}$ from the sample surface (Fig. 1A).

The reactor 2 used a SSUV $1.6 \mathrm{~K}\left(\right.$ Sciencetech $\left.^{\mathbb{R}}\right)$ solar simulator with power set at $957 \mathrm{~W}$. This equipment simulates any set solar light input without depending on weather conditions. The incident radiance was simulated from meteorological database for the period between 9 a.m. and 16 p.m. The sample was positioned $100 \mathrm{~cm}$ from the light source. The solar simulator was isolated in a closed compartment to reduce the interference of the external light. Fig. 1B shows a schematic diagram for this process.

The third reactor was constructed using a UV-A LED. A cylindrical container containing a quartz LED system was coupled to the central annulus of the reactor. The container was placed in solution (Fig. 1C). Each LED used was $100 \mathrm{mcd}, \lambda=385 \mathrm{~nm}$ and $0.12 \mathrm{~W}$. A triangular bar with a 69 UV-A LED capacity was used, but only 24 LED were applied. The outside of the reactor was coated with an aluminum reflector to improve reflectance.

The disinfection tests were carried out using $0.5 \mathrm{~g} \mathrm{~L}^{-1}$ photocatalyst in suspension for all three sources of radiation. Preliminary data shows that the $0.5 \mathrm{~g} \mathrm{~L}^{-1}$ concentration was efficient in microbial inactivation. Besides, this concentration has been previously established in many recent related studies by Cho et al. (2004); Zhang et al. (2012) and Siyahi et al. (2015). Helali et al. (2014) demonstrated that an increase in photocatalyst concentration (above $0.5 \mathrm{~g} \mathrm{~L}^{-1}$ ) did not necessarily yield a linear efficiency increase. Gogate and Pandit (2004) noted that a concentration increase may as well cause particles to aggregate and result in a lower surface area. A higher concentration can also increase medium turbidity, thus interfering with photonic energy penetration and, ultimately, photodegradation.

A total volume of $450 \mathrm{~mL}$ of each solution was treated. Experimental runs were performed by irradiation in the absence of photocatalyst (photolysis process). The radiation intensity was measured by a radiometer (Solar Light PMA 2200) and the results for mercury vapor lamp, solar simulator and UV-A LED were $6.8,4.2$ and $0.16 \mathrm{~mW} \mathrm{~cm}^{-2}$ respectively. Exposure times were: $0,15,30$ and $60 \mathrm{~min}$. After irradiation, the samples were filtered using a $0.45 \mathrm{~mm}$ cellulose membrane (Sartorius ${ }^{\mathbb{R}}$ ) to remove any photocatalyst in suspension. The experiments were conducted in duplicate.

\subsection{Water sampling}

The experiments were conducted using raw water from the Piracicaba River, located at Piracicaba, São Paulo, Brazil, collected at the river bank, near the pumping system inlet of the water treatment plant (Water Treatment Plant 1, Luiz de Queiroz, SEMAE, $\left.22^{\circ} 42^{\prime} 50.54^{\prime \prime} \mathrm{S}, 47^{\circ} 38^{\prime} 56.77^{\prime \prime} \mathrm{O}\right)$. The samples were collected in November 2012.

\subsection{Quantitative determination of total coliforms}

Total coliforms have been determined by the membrane filter method and the results expressed as CFU $100 \mathrm{~mL}^{-1}$ (colony forming units per $100 \mathrm{~mL}$ ) according to APHA (2005). Cultures of total coliforms were composed of Escherichia, Citrobacter, Enterobacter and Klebsiella, considered to be indicators of fecal matter contamination with natural occurrence in soil and water.

\subsection{Determination of inactivation level - kinetic study}

Bacterial inactivation rate was estimated by Chick's Law, which 

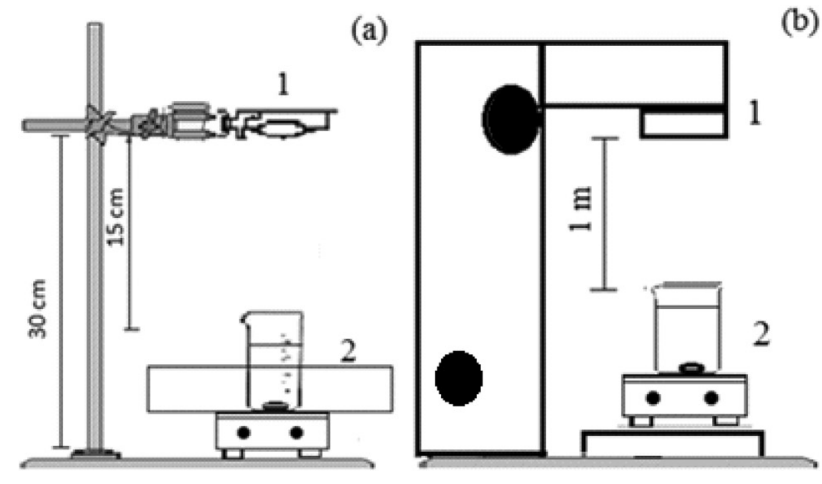

(b)

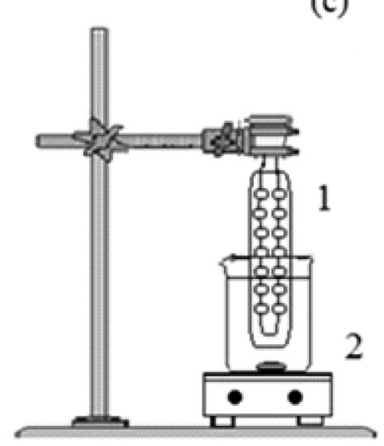

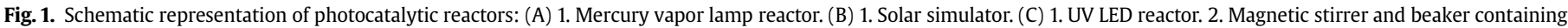
sample.

states that the removal rate is directly proportional to the concentration of bacteria in a first-order reaction. The Equation (1) presents this relation in linear form:

$\ln N / N_{0}=-\mathrm{k} \mathrm{t}$

where $\mathrm{N}$ is the colony count of the UV irradiated sample and $\mathrm{N}_{0}$ is the colony count of the sample before UV irradiation, $\mathrm{k}$ is the inactivation constant and $\mathrm{t}$ is the contact time.

The constant (k) was obtained by linear regression analysis, plotted and linearized by the OriginPro 9.0 software (OriginLab). According to the Chick's law, the slope is negative $(-\mathrm{k})$. For each dose of irradiation light, there is a value of k. Equation (2) represents a line through central coordinates with a -k slope:

$\mathrm{y}=\ln N / N_{0} ; \mathrm{A}=\mathrm{k}$ and $\mathrm{x}=\mathrm{t}$, therefore $\mathrm{y}=\mathrm{Ax}$

The radiation dose in UV inactivation is defined as the product of the intensity of ene'rgy and the exposure time:

$\mathrm{D}=\mathrm{I} \cdot \mathrm{t}$

where $\mathrm{D}$ is the ultraviolet radiation dose $\left(\mathrm{mW} . \mathrm{s} \mathrm{cm}^{-2}\right)$, I is the radiation intensity $\left(\mathrm{mW} . \mathrm{cm}^{-2}\right)$ and $\mathrm{t}$ is the exposure time (min).

In this work, we used a $58 \times 10^{1} \mathrm{~mW} . \mathrm{s} \mathrm{cm}^{-2}$ dose for the three treatments. The photocatalytic treatment using vapor lamp duration was $1.41 \mathrm{~min}(84.6 \mathrm{~s})$, whereas the solar simulator treatment duration was $2.29 \mathrm{~min}(137 \mathrm{~s}$ ) and the UV-A LED treatment duration was $60 \min \left(3.60 \times 10^{3} \mathrm{~s}\right)$.

According to Equation (4), N/No is the fraction of surviving bacteria after an exposure time $\mathrm{t}$ :

$N / N_{0}=\mathrm{e}^{-\mathrm{kt}}$

Thus, the inactivation percentage was calculated using the Equation (5):

Inactivation percentage $(\%)=\left(1-N / N_{0}\right) \times 100$

\subsection{Experimental design}

The experimental design to evaluate the efficiency of the system was developed by using the software Minitab ${ }^{\circledR} 171.0$ (Minitab Inc.) A factorial design with 2 independent variables as photocatalysts and irradiation source was applied according to Table 1 . The concentration of photocatalyst used in all reactions $\left(0.5 \mathrm{~g} \mathrm{~L}^{-1}\right)$ was optimized based on results of preliminary experiments and literature values. The comparison between different light sources was
Table 1

Independent variables of the factorial design of experiments.

\begin{tabular}{lllll}
\hline Independent variable & Factor & Range & & \\
\hline Photocatalyst & A & Photolysis & SiZnO & F-N-SiZnO \\
Irradiation source & B & Mercury vapor & Solar simulator & UV LED \\
\hline
\end{tabular}

evaluated in relation to the normalized dose $\left(\mathrm{mWs} \mathrm{cm}^{-2}\right)$, since each light source had a different power. The dependent variable (response) was expressed as inactivation percentage of total coliforms (\%).

The regression curve fit was expressed by the coefficient of determination $\left(R^{2}, R^{2} a d j\right)$ and statistical significance was verified by ANOVA calculation through F-value and p-value. Model parameters were selected based on their probability values insertion within $95 \%$ confidence levels. Hence, we evaluated the effects of each of the factors and their interaction on the overall efficiency of the photocatalytic process.

\section{Results and discussion}

The parameters from Chick's Law regression for each treatment duration are presented in Table 2 . The unit of $\mathrm{k}$ is $\mathrm{min}^{-1}$, since it is a first order reaction in relation to the concentration of microorganisms.

From Table 2, we observed that the experimental data pattern correlates to Chick's Law, with a small offset from the model, as evidenced by $R^{2}$. Thus, the inactivation of coliforms efficiency was calculated as expressed in Fig. 2.

As shown in Fig. 2, the UV-A LED light source for inactivation of coliforms without photocatalysts yielded $85 \%$ efficiency with doses of $58 \times 10^{1} \mathrm{~mW} . \mathrm{cm}^{-2}$. Mercury vapor lamp and solar simulator

Table 2

Inactivation constant and $\mathrm{R}^{2}$ values obtained by Chick's law for inactivation of tota coliforms using different light sources and photocatalysts.

\begin{tabular}{|c|c|c|c|c|c|c|}
\hline \multirow{3}{*}{$\begin{array}{l}\text { Dose }\left(\mathrm{mWs} \mathrm{cm}^{-2}\right) \\
\text { Time (min) }\end{array}$} & \multicolumn{2}{|c|}{$\begin{array}{l}\text { Mercury vapor } \\
\text { lamp }\end{array}$} & \multicolumn{2}{|c|}{ Solar simulator } & \multicolumn{2}{|l|}{ UV LED } \\
\hline & \multicolumn{2}{|c|}{$\begin{array}{l}58 \times 10^{1} \\
1.41(84.6 \mathrm{~s})\end{array}$} & \multicolumn{2}{|c|}{$\begin{array}{l}58 \times 10^{1} \\
2.29(137 \mathrm{~s})\end{array}$} & \multicolumn{2}{|c|}{$\begin{array}{l}58 \times 10^{1} \\
60\left(3.60 \times 10^{3} \mathrm{~s}\right)\end{array}$} \\
\hline & $\mathrm{k}\left(\min ^{-1}\right)$ & $\mathrm{R}^{2}$ & $\mathrm{k}\left(\min ^{-1}\right)$ & $\mathrm{R}^{2}$ & $\mathrm{k}\left(\min ^{-1}\right)$ & $\mathrm{R}^{2}$ \\
\hline Photolysis & -0.15798 & 0.99 & -0.06258 & 0.97 & -0.03188 & 0.97 \\
\hline $\mathrm{TiO}_{2}$ & -0.51934 & 1 & -0.16124 & 0.99 & -0.05734 & 0.94 \\
\hline SiZno & -0.34176 & 0.99 & -0.12984 & 0.99 & -0.06712 & 0.94 \\
\hline N-SiZnO & -0.22269 & 0.96 & -0.10766 & 0.99 & -0.05822 & 0.91 \\
\hline $\mathbf{F}-\mathbf{N}-\mathrm{SiZnO}$ & -0.36154 & 0.98 & -0.11828 & 0.97 & -0.05083 & 0.94 \\
\hline
\end{tabular}




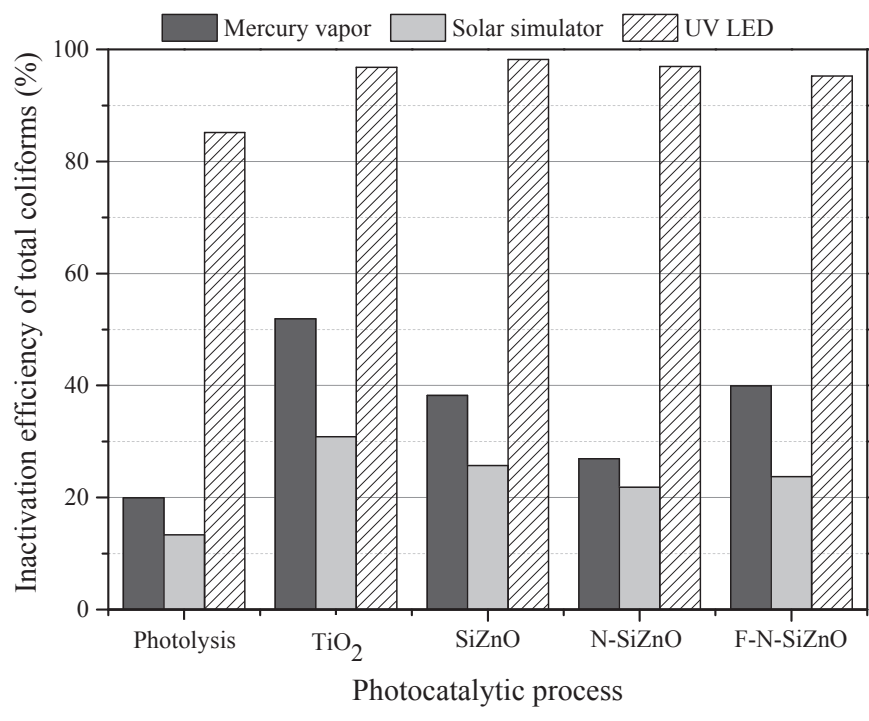

Fig. 2. Inactivation of coliforms efficiency using different photocatalytic treatments after exposure to different light sources with dose of $58 \times 10^{1} \mathrm{~mW} . \mathrm{s} \mathrm{cm}^{-2}$.

photolysis reached values of $19 \%$ and $13 \%$, respectively, with the same light dosage.

The highest photocatalytic efficiency in the inactivation of coliforms was obtained by UV-A LED in the present study. Ordered by efficiency, $\mathrm{SiZnO}$ with $\mathrm{TiO}_{2}$ had the highest value (98\%), followed by $\mathrm{N}-\mathrm{SiZnO}$ with $(96 \%)$ and then $\mathrm{F}-\mathrm{N}-\mathrm{SiZnO}(95 \%)$ as presented in Figs. 2 and 4 . With a mercury vapor lamp, $\mathrm{TiO}_{2}$ showed the highest efficiency at $52 \%$, followed by the photocatalyst synthesized $\mathrm{F}-\mathrm{N}$ -SiZnO (40\%) and SiZnO (38\%). By using the solar simulator, the $\mathrm{TiO}_{2}$ showed a $31 \%$ inactivation ratio, followed by $\mathrm{SiZnO}$ with $26 \%$.

Mercury vapor lamps have been considered as the main source of artificial UV in microbial inactivation protocols for a long time. However, due to damage and exposition risks, new UV light sources have been investigated. Besides, non-toxic, cost-effective and efficient alternatives are preferable (Vatansever et al., 2013).

Although Karunakaran et al. (2016), among others, have proven high photocatalytic efficiency of mercury vapor lamps, the inactivation of microorganisms in our study was more efficient with UVLED. According to Gonçalves (2003), the major factors contributing to reduced efficiency in mercury vapor lamps radiation are both mercury deposition on the lamp walls and case solarization.

In this context, LED lamps have arisen as an alternative for being a solid state semiconductor capable of transforming electrical energy into light, being able to produce more UV light than an incandescent lamp heat, which makes it more efficient by saving up to $50 \%$ more energy compared to traditional sources (Chen et al., 2005; Miller et al., 2013). This fact also explains the high performance of UV-A LED in relation to mercury vapor lamp and the solar simulator used for the inactivation of coliforms in this work However, the UV LED disinfection technology is still considered a "work in progress technology" by most researchers and manufacturers (Ibrahim et al., 2014; Lui et al., 2014).

The sun is a source of ultraviolet light in all its electromagnetic spectrum; however, the atmospheric ozone layer prevents significant amounts of radiation in this range to reach the Earth's surface (Galvez and Rodriguez, 2003). UV radiation levels reaches only 10-30\% depending on the latitude, thus explaining the low efficiency in the total coliforms inactivation when replicated by the solar simulator applied in our work.

The inactivation percentage after photolysis was lower than inactivation by heterogeneous photocatalysis in all of the three radiation sources, thus demonstrating the influence of the photocatalyst, corroborated by statistical analysis (Figs. 3 and 4).

In this process, the combination of pairs electrons $\left(\mathrm{e}^{-}\right)$and holes $\left(\mathrm{h}^{+}\right)$occurs by energy absorption. The pair can undergo internal recombination or migrate to the catalyst surface. On the surface, it can suffer external recombination or participate in redox reactions with absorption of $\mathrm{H}_{2} \mathrm{O}, \mathrm{OH}^{-}$and $\mathrm{O}_{2}$. The oxidation reactions occur between the gap of the valence band and water or hydroxyl ions, producing the radical $\mathrm{OH}^{\bullet}$. The reduction reactions can occur between the electron conduction band and oxygen, producing $\mathrm{O}_{2}^{--}$, which produces $\mathrm{H}_{2} \mathrm{O}_{2}$ (Fu et al., 2005; Chong et al., 2010; Bak et al., 2012; Wang et al., 2014; Wu et al., 2014). The higher the energy dose, the greater the combination of pairs $\mathrm{e}-/ \mathrm{h}+$. The process also leads to higher production of $\mathrm{OH}^{\bullet}$ radicals, allowing a faster and more efficient photocatalytic degradation.

Principal effects and interaction between treatment variables during inactivation of coliforms are shown in Figs. 3 and 4.

The $\mathrm{TiO}_{2}$ photocatalyst performed better than the other two light sources (Fig. 3) due to their grain size, followed by the synthesized photocatalyst SiZnO and F-N-SiZnO. However, when only light is taken into account, the UV LED stood out, reaching inactivation efficiencies of total coliforms in $99 \%$, which can also be seen in Fig. 4. As for the UV LED, all synthesized photocatalysts showed a higher inactivation performance for microorganisms.

By incorporating no-metals, metalloids and transition metals to synthesized photocatalysts, causes a shift towards larger wavelengths, hence causing an increased photocatalytic activity due photogenerated charges (Shi et al., 2011; Ananpattarachai and Boonto, 2015). Furthermore, Estruga et al. (2010) discovered that silicon-doped electrodes increased catalyst surface area. However, the $\mathrm{TiO}_{2}$ has a large surface area (around $50 \mathrm{~m}^{2} . \mathrm{g}^{-1}$ ) and its complex crystalline microstructure promotes better charge separation which inhibits recombination (Lopes et al., 2011), resulting in a better performance in degrading processes.

The high efficiency in the inactivation of total coliforms by heterogeneous photocatalysis (Fig. 4) may be due to the combination of two processes: (i) the cell damage and degradation caused by $\mathrm{OH}^{\bullet}$ radicals on the surface of the photocatalyst, and (ii) the direct absorption of UV radiation by the cells, greatly contributing to further cell inactivation. The UV LED based disinfection has been previously demonstrated alone (Hanamoto et al., 2007; Mori et al., 2007; Yagi et al., 2007) and in combination with UV-C (Chevremont et al., 2012a, 2012b).

Hanamoto et al. (2007) tested the disinfection mechanisms of a UV LED at $365 \mathrm{~nm}$ for E. coli, Vibrio parahaemolyticus and S. aureus. They added mannitol, an antioxidant known to capture hydroxyl radicals, and catalase, an enzyme that transforms $\mathrm{H}_{2} \mathrm{O}_{2}$ in water $\left(\mathrm{H}_{2} \mathrm{O}\right)$. These products significantly reduced the disinfection efficiency of UV LED.

Matsunaga et al. (1985) investigated for the first time, the antimicrobial effect of $\mathrm{TiO}_{2}$ photocatalytic reaction. These authors reported the effectiveness of the photocatalytic oxidation in water with several microorganisms, including Lactobacillus acidophilus, Saccharomyces cerevisiae, E. coli and Chlorella vulgaris.

Detailed studies on the bactericidal effect of heterogeneous photocatalysis were also carried out by Huang et al. (2000); Cho et al. (2004); Hanamoto et al. (2007) and Wu et al. (2014). According to these researchers, the sequence of events that leads to bacterial inactivation start at the oxidative damage to cell walls. The underlying cell membrane is further damaged as it progressively increases permeability, allowing intracellular content outflow and ultimately causing cellular death. In addition, there may be a direct attack of cells by dispersed particles from the photocatalyst. These particles react to intracellular components of cells with damaged membranes, which accelerate cell inactivation. In certain doses, the 


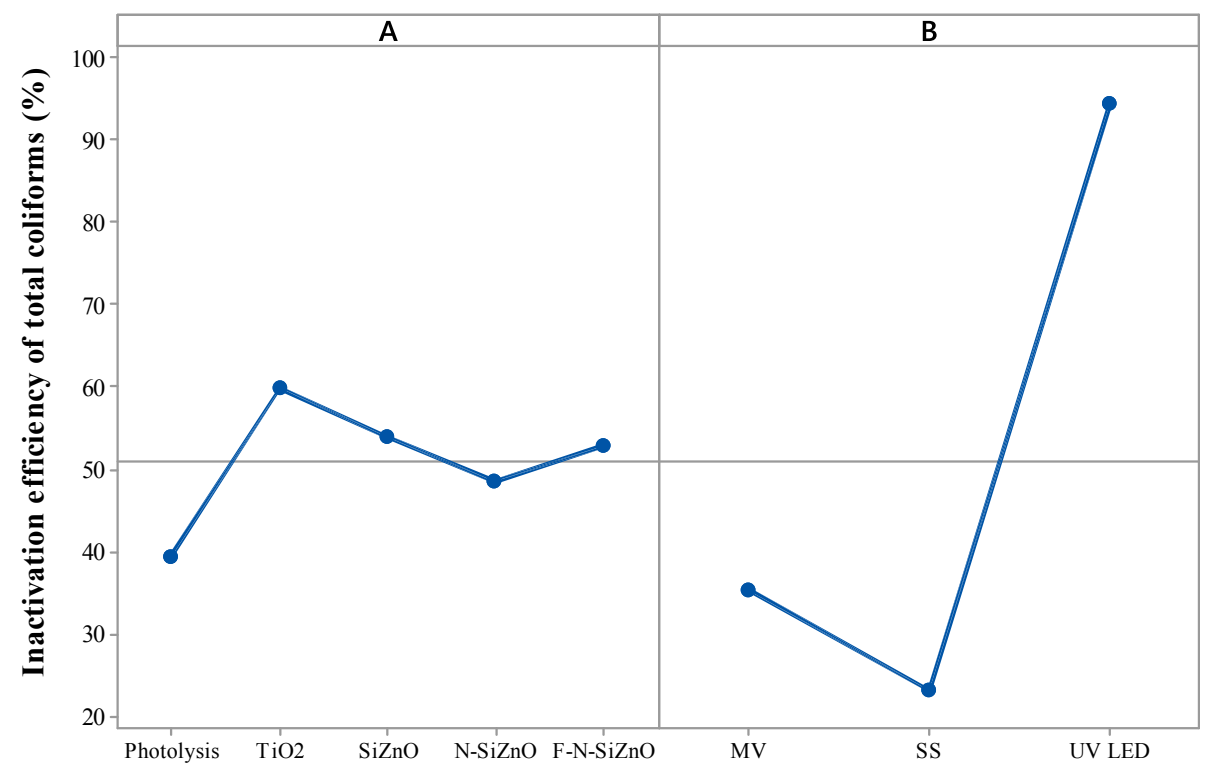

Fig. 3. Principal effects plot between light and photocatalysts for inactivation of total coliforms. A: Photocatalysts; B: Light sources.

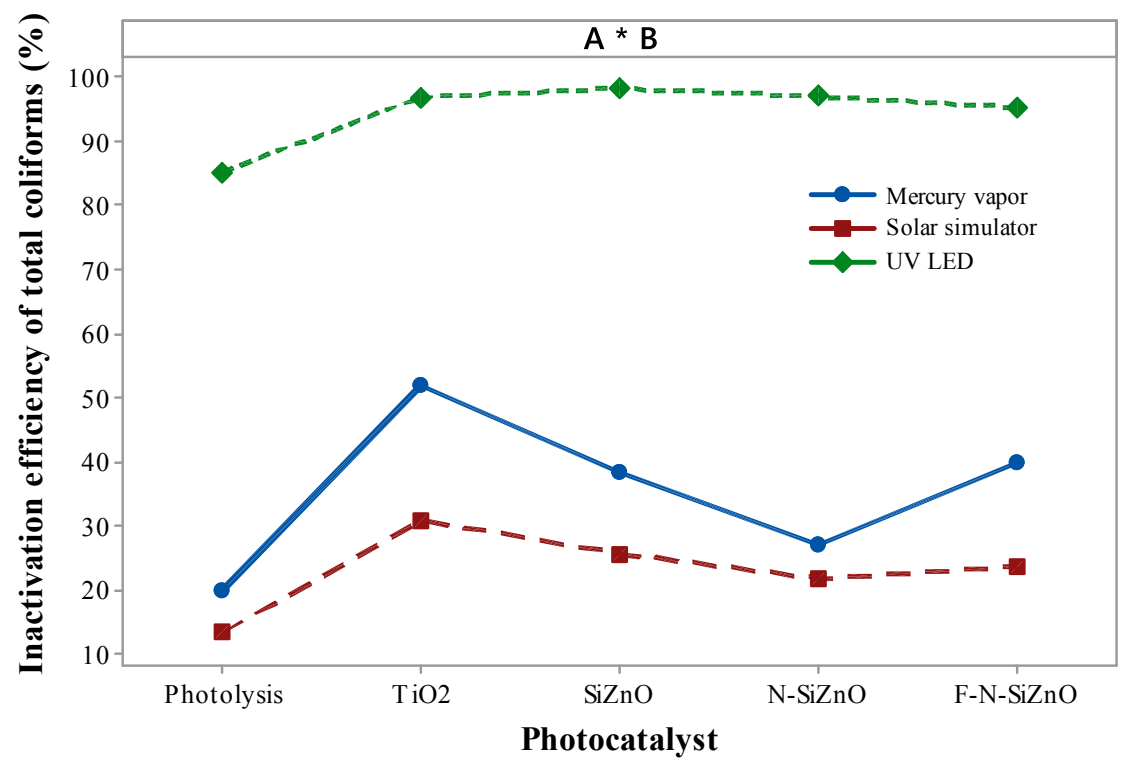

Fig. 4. Interaction plot between light and photocatalysts for inactivation of total coliforms. A: Photocatalysts; B: Light sources.

absorption of UV radiation by the DNA can inhibit cellular ability to reproduce, causing death or mutations. The longer the UV incidence, the greater the chances of nucleotide modifications and DNA damage. Other studies have suggested that the mode of action is the photooxidation of coenzyme A, leading to the inhibition of cell respiration and, as a result, death (Vohra et al., 2005).

According to Cho et al. (2004), there is a well-established linear relationship between the amount of $\mathrm{OH}^{\cdot}$ radical and the inactivation of $E$. coli as primarily responsible for the inactivation of microorganisms by disinfection when $\mathrm{TiO}_{2} / \mathrm{UV}$ are applied. Ibañez et al. (2003) also attributed the bacterial inactivation to the radical $\mathrm{OH} \cdot$ by photocatalysis with $\mathrm{TiO}_{2}$. Studies by Rincon and Pulgarin (2004) in absence of light detected no bactericidal effect of $\mathrm{TiO}_{2}$ in a slurry with a pure culture of $E$. coli K12 (ATCC 23716).

Melián et al. (2000) studied the inactivation of coliforms using UV lamp with $\mathrm{TiO}_{2}$ and managed to reduce the microbial concentration to $9 \times 10^{2} \mathrm{CFU} \mathrm{mL} \mathrm{mL}^{-1}$. The authors also compared the effects of UV lamp with solar disinfection and reported that solar disinfection is slower due to the UV radiation fraction being lower than the actual sunlight radiation, hence corroborating results observed in our work.

Mori et al. (2006) investigated the inactivation of $E$. coli and Vibrio parahaemolyticus by using eight serial UV LED at $365 \mathrm{~nm}$ wavelength. The result showed $100 \%$ inactivation for $E$. coli and Vibrio parahaemolyticus in $30 \mathrm{~min}$ and $10 \mathrm{~min}$ of treatment, respectively. These results also demonstrate the high efficiency of UV LED induced bacterial inactivation.

Ananpattarachai and Boonto (2015) studied N-doped $\mathrm{TiO}_{2}$ nanoparticles and $\mathrm{Ni}$-doped $\mathrm{TiO}_{2}$ towards the inactivation of $S$. aureus and $E$. coli using visible light. The $\mathrm{N}$-doped $\mathrm{TiO}_{2}$ nanoparticles were more efficient than Ni-doped $\mathrm{TiO}_{2}$, due to narrower band gap promoted by $\mathrm{N}$-doped nanoparticles. 
Despite the actual inactivation efficacy by heterogeneous photocatalysis, the practical application of photocatalysts in water treatment still undergoes technical challenges to reduce cost in water treatment plants. The main issue lies in the steps required for material removal rough water filtration. These are the main causes for increased costs of photocatalysts application. Therefore, UV LED can be suggested as a sole disinfectant agent, according to the most efficient results towards inactivation of coliforms in this study.

\section{Conclusions}

All photocatalysts used in this work showed photocatalytic activity in a $0.5 \mathrm{~g} \mathrm{~L}^{-1}$ concentration over all three radiation sources capable of inactivating total coliforms in water from the Piracicaba River, São Paulo, Brazil. Their efficiency, however, differed greatly.

Radiation by mercury vapor lamp and solar simulator in combination with heterogeneous photocatalysis was effective in the inactivation of microorganisms, but the maximum effect on inactivation of microorganisms occurred when using the UV-A LED. The results obtained with the UV-A LED showed that only the silicondoped photocatalyst, SiZnO, inactivation reached values of total coliforms greater than $\mathrm{TiO}_{2}$ (98\%), but the efficiencies are very similar to other synthesized photocatalysts. The photocatalysis was more efficient than photolysis.

The use of UV-A LED as the light source without the photocatalyst is promising, due to its lower costs. This allows the direct application of UV to a water treatment plant for inactivation of microorganisms, thus reducing the need for chlorine addition and the subsequent formation of organohalogen compounds.

\section{Acknowledgements}

The authors would like to acknowledge the CAPES and FAPESP for the financial support.

\section{References}

Ananpattarachai, J., Boonto, Y., 2015. Visible light photocatalytic antibacterial activity of Ni-doped and $\mathrm{N}$-doped $\mathrm{TiO}_{2}$ on Staphylococcus aureus and Escherichia coli bacteria. Environ. Sci. Pollut. R. 1-9. http://dx.doi.org/10.1007/s11356-0154775-1.

APHA. American Public Health Association, 2005. Standard Methods for the Examination of Water and Wastewater. APHA/AWWA, Washington.

Bak, T., Nowotny, J., Sucher, N.J., Wachsman, E.D., 2012. Photocatalytic water disinfection on oxide semiconductors: Part 1 - basic concepts of $\mathrm{TiO}_{2}$ photocatalysis. Adv. Appl. Ceram. 111 (1-2), 4-15. http://dx.doi.org/10.1179/ 1743676111Y.0000000036.

Chen, D.H., Ye, X., Li, K., 2005. Oxidation of PCE with a UV LED photocatalytic reactor. Chem. Eng. Technol. 28 (1), 95-97. http://dx.doi.org/10.1002/ ceat.200407012.

Chen, H., Xie, Z., Jin, X., Luo, C., You, C., Tang, Y., Chen, D., Li, Z., Fan, X., 2012. TiO 2 and N-Doped $\mathrm{TiO}_{2}$ induced photocatalytic inactivation of Staphylococcus aureus under $405 \mathrm{~nm}$ LED blue light irradiation. Int. J. Photoenergy 2012, 1-5. http:// dx.doi.org/10.1155/2012/848401.

Chevremont, A.C., Farnet, A.M., Coulomb, B., Boudenne, J.L., 2012a. Effect of coupled UV-A and UV-C LEDs on both microbiological and chemical pollution of urban wastewaters. Sci. Total Environ. 426 (1), 304-310. http://dx.doi.org/10.1016 j.scitotenv.2012.03.043.

Chevremont, A.C., Farnet, A.M., Sergent, M., Coulomb, B., Boudenne, J.L., 2012b. Multivariate optimization of fecal bioindicator inactivation by coupling UV-A and UV-C LEDs. Desalination 285 (2012), 219-225. http://dx.doi.org/10.1016/ j.desal.2011.10.006.

Cho, M., Chung, H., Choi, W., Yoon, J., 2004. Linear correlation between inactivation of $E$. coli and $\mathrm{OH}$ radical concentration in $\mathrm{TiO}_{2}$ photocatalytic disinfection. Water Res. 38 (4), 1069-1077. http://dx.doi.org/10.1016/j.watres.2003.10.029.

Chong, M.N., Jin, B., Chow, C.W.K., Saint, C., 2010. Recent developments in photocatalytic water treatment technology: a review. Water Res. 44 (10), 2997-3027. http://dx.doi.org/10.1016/j.watres.2010.02.039.

Dyck, R., Cool, G., Rodriguez, M., Sadiq, R., 2015. Treatment, residual chlorine and season as factors affecting variability of trihalomethanes in small drinking water systems. Front. Environ. Sci. Eng. 9 (1), 171-179. http://dx.doi.org/ $10.1007 / \mathrm{s} 11783-014-0750-1$.

Elamin, N., Elsanousi, A., 2013. Synthesis of $\mathrm{ZnO}$ Nanostructures and their photocatalytic activity. J. Appl. Ind. Sci. 1 (1), 32-35.

Estruga, M., Domingo, C., Domènech, X., Ayllón, J.A., 2010. Zirconium-doped and silicon-doped $\mathrm{TiO}_{2}$ photocatalysts synthesis from ionic-liquid-like precursors. J. Colloid Interface Sci. 344 (2), 327-333. http://dx.doi.org/10.1016/ j.jcis.2009.12.063.

Fu, G., Vary, P.S., Lin, C., 2005. Anatase $\mathrm{TiO}_{2}$ nanocomposites for antimicrobial coatings. J. Phys. Chem. B 109 (18), 8889-8898. http://dx.doi.org/10.1021/ jp0502196.

Galvez, J.B., Rodriguez, S.M., 2003. Solar detoxification. United Nations Educational, Scientific and Cultural Organization, Spain.

Gogate, P., Pandit, A., 2004. A review of imperative technologies for wastewater treatment. Adv. Environ. Res. 8, 501-551. http://dx.doi.org/10.1016/S10930191(03)00031-5.

Gonçalves, R.F., 2003. Disinfection of Wastewater. ABES,Rima, Rio de Janeiro.

Gulyas, H., 2014. Solar heterogeneous photocatalytic oxidation for water and wastewater treatment: problems and challenges. J. Adv. Chem. Eng. 4 (2), 1-11. http://dx.doi.org/10.4172/2090-4568.1000108.

Hanamoto, A., Mori, M., Takashi, A., Nakano, M., Wakikawa, N., Akutagawa, M., Ikehara, T., Nakaya, Y., Kinouchi, Y., 2007. New water disinfection system using UVA light-emitting diodes. J. Appl. Microbiol. 103 (2007), 2291-2298. http:// dx.doi.org/10.1111/j.1365-2672.2007.03464.x.

Helali, S., Polo-López, M.I., Fernández-Ibáñez, P., Ohtani, B., Amano, F., Malato, S., Guillard, C., 2014. Solar photocatalysis: a green technology for E. coli contaminated water disinfection. Effect of concentration and different types of suspended catalyst. J. Photochem. Photobiol. A Chem. 276, 31-40. http:// dx.doi.org/10.1016/j.jphotochem.2013.11.011.

Huang, L.H., Sun, C., Liu, Y.L., 2007. Pt/N-codoped $\mathrm{TiO}_{2}$ nanotubes and its photocatalytic activity under visible light. Appl. Surf. Sci. 253 (17), 7029-7035. http:// dx.doi.org/10.1016/j.apsusc.2007.02.048.

Huang, Z., Maness, P., Blake, D.M., Wolfrum, E.J., Smolinski, S.L., 2000. Bactericidal mode of titanium dioxide photocatalysis. J. Photochem. Photobiol. A Chem. 130 (2-3), 163-170. http://dx.doi.org/10.1016/S1010-6030(99)00205-1.

Ibáñez, J.A., Litter, M.I., Pizarro, R.A., 2003. Photocatalytic bactericidal effect of $\mathrm{TiO}_{2}$ on Enterobacter cloacae: comparative study with other Gram (-) bacteria. J. Photochem. Photobiol. A Chem. 157 (1-124), 81-85. http://dx.doi.org/10.1016/ S1010-6030(03)00074-1.

Ibrahim, M.A.S., MacAdam, J., Autin, O., Jefferson, B., 2014. Evaluating the impact of LED bulb development on the economic viability of ultraviolet technology for disinfection. Environ. Technol. 35 (4), 400-406. http://dx.doi.org/10.1080/ 09593330.2013.829858.

Karunakaran, C., Vinayagamoorthy, P., Jayabharathi, J., 2016. Enhanced photocatalytic activity of magnetically separable bactericidal $\mathrm{CuFe}_{2} \mathrm{O}_{4}$-embedded $\mathrm{Ag}$ deposited ZnO nanosheets. RSC Adv. 6, 1782-1792. http://dx.doi.org/10.1039/ C5RA20958G.

Li, Y., Jiang, Y., Penh, S., Jiang, F., 2010. Nitrogen-doped $\mathrm{TiO}_{2}$ modified with $\mathrm{NH}_{4} \mathrm{~F}$ for efficient photocatalytic degradation of formaldehyde under blue light-emitting diodes. J. Hazard. Mater. 182 (1-3), 90-96. http://dx.doi.org/10.1016/ j.jhazmat.2010.06.002.

Lin, D., Guo-Xi, C., Ying, M., Xia-Lin, J., Guo-Tian, Y., Shao-Kang, G., 2009. Enhanced photocatalytic degradation properties of nitrogen-doped titania nanotube arrays. Trans. Nonferrous Metals Soc. China 19, 1583-1587. http://dx.doi.org/ 10.1016/S1003-6326(09)60074-1.

Liu, H., Liu, G., Xie, G., Zhang, M., Hou, Z., He, Z., 2011. Gd ${ }^{3+}$, N-codoped trititanate nanotubes: preparation, characterization and photocatalytic activity. Appl. Surf Sci. 257 (8), 3728-3732. http://dx.doi.org/10.1016/j.apsusc.2010.11.122.

Lopes, P.R.M., Montagnolli, R.N., Bidoia, E.D., 2011. Analytical methods in photoelectrochemical treatment of phenol. J. Braz. Chem. Soc. 22 (9), 1758-1764. http://dx.doi.org/10.1590/S0103-50532011000900019.

Lopes, P.R.M., Montagnolli, R.N., Bidoia, E.D., 2012. Photocatalytic degradation of phenol by thermal titanium dioxide thin layer electrodes. Water Air Soil Pollut. 223 (7), 3673-3688. http://dx.doi.org/10.1007/s11270-012-1140-6.

Lui, G.Y., Roser, D., Corkish, R., Ashbolt, N., Jagals, P., Stuetz, R., 2014. Photovoltaic powered ultraviolet and visible light-emitting diodes for sustainable point-ofuse disinfection of drinking waters: a review. Sci. Total Environ. 493 (2014), 185-196. http://dx.doi.org/10.1016/j.scitotenv.2014.05.104.

Matsunaga, T., Tomada, R., Nakajima, T., Wake, H., 1985. Photochemical sterilization of microbial cells by semiconductor powders. FEMS Microbiol. Lett. 29 (1-2), 211-214. http://dx.doi.org/10.1111/j.1574-6968.1985.tb00864.x.

Miller, S.L., Linnes, J., Luongo, J., 2013. Ultraviolet germicidal irradiation: future directions for air disinfection and building applications. Photochem Photobiol. 89 (4), 777-781. http://dx.doi.org/10.1111/php.12080.

Melián, J.A.H., Rodríguez, J.M.D., Suárez, A.V., Rendón, E.T., Campo, C.V., Arana, J., Peña, J.P., 2000. The photocatalytic disinfection of urban waste waters. Chemosphere 41 (2000), 323-327. http://dx.doi.org/10.1016/S0045-6535(99) 00502-0.

Mori, M., Hamamoto, A. Nakano, M. Akutagawa, M., Takahashi, A Ikehara, T. Kinouchi, Y., 2006. Effects of ultraviolet LED on bacteria. World Congr. Med. Phys. Biomed. Eng. 14, 1327-1330.

Mori, M., Hamamoto, A., Takahashi, A., Nakano, M., Wakikawa, N., Tachibana, S., Ikehara, T., Nakaya, Y., Akutagawa, M., Kinouchi, Y., 2007. Development of a new water sterilization device with a $365 \mathrm{~nm}$ UV LED. Med. Bio. Eng. Comput. 45, 1237-1241. http://dx.doi.org/10.1007/s11517-007-0263-1.

Nickheslat, A., Amin, M.M., Izanloo, H., Fatehizadeh, A., Mousavi, S.M., 2013. Phenol photocatalytic degradation by advanced oxidation process under ultraviolet radiation using titanium dioxide. J. Environ. Public Health 2013 (2013), 1-9. 
http://dx.doi.org/10.1155/2013/815310.

Rengifo-Herrera, JA, Mielczarski, E, Mielczarski, J, Castillo, N.C. Kiwi, J. Pulgarin, C., 2008. Escherichia coli inactivation by N, S, co-doped commercial $\mathrm{TiO}_{2}$ powders under UV and visible light. Appl. Catal. B Environ. 84, 448-456. http://dx.doi.org/10.1016/j.apcatb.2008.04.030.

Rincón, A., Pulgarin, C., 2004. Bactericidal action of illuminated $\mathrm{TiO}_{2}$ on pure Escherichia coli and natural bacterial consortia: post-irradiation events in the dark and assessment of the effective disinfection time. Appl. Catal. B Environ. 49 (2), 99-112. http://dx.doi.org/10.1016/j.apcatb.2003.11.013.

Rizzo, L., Sannino, D., Vaiano, V., Sacco, O., Scarpa, A., Pietrogiacomi, D., 2014. Effect of solar simulated $\mathrm{N}$-doped $\mathrm{TiO}_{2}$ photocatalysis on the inactivation and antibiotic resistance of an E. coli strain in biologically treated urban wastewater. Appl. Catal. B Environ. 144, 369-378. http://dx.doi.org/10.1016/ j.apcatb.2013.07.033.

Schneider, J., Matsuoka, M., Takeuchi, M., Zhang, J., Horiuchi, Y., Anpo, M. Bahnemann, D.W., 2014. Understanding $\mathrm{TiO}_{2}$ photocatalysis: mechanisms and materials. Chem. Rev. 114 (19), 9919-9986. http://dx.doi.org/10.1021/ cr5001892.

Siyahi, V., Habibi-Yangjeh, A., Latifi-Navid, S., Asadi, Asadollah, 2015. Microwaveassisted one-pot preparation of $\mathrm{AgBr} / \mathrm{ZnO}$ nanocomposites as highly efficient visible-light photocatalyst for inactivation of Escherichia coli. Mater. Express 5 (3), 201-210. http://dx.doi.org/10.1166/mex.2015.1230.

Shi, W. Chen, Q. Xu, Y. Wu, D., Huo, C.F., 2011. Investigation of the silicon concentration effect on $\mathrm{Si}$-doped anatase $\mathrm{TiO}_{2}$ by first-principles calculation. J. Solid State Chem. 184 (8), 1983-1988.

Tan, Y.N., Wong, C.L., Mohamed, A.R., 2011. An Overview on the photocatalytic activity of nano-doped- $\mathrm{TiO}_{2}$ in the degradation of organic pollutants. Int. Sch. Res. Netw. 2011, 1-8. http://dx.doi.org/10.5402/2011/261219.

Umebayashi, T., Yamaki, T., Yamamoto, S., Miyashita, A., Tanaka, S., Sumita, T., Asai, K., 2003. Sulfur-doping of rutile-titanium dioxide by ion implantation: photocurrent spectroscopy and first-principles band calculation studies. J. Appl. Phys. 93 (9), 5156-5160. http://dx.doi.org/10.1063/1.1565693.

Vatansever, F., Ferraresi, C., Sousa, M.V.P., Yin, R., Rineh, A., Sharma, S.K. Hamblin, M., 2013. Can biowarfare agents be defeated with light? Virulence 4
(8), 796-825. http://dx.doi.org/10.4161/viru.26475.

Vohra, A., Goswami, D.Y., Deshpande, D.A., Block, S.S., 2005. Enhanced photocatalytic inactivation of bacterial spores on surfaces in air. J. Ind. Microbiol. Biotechnol. 32 (8), 364-370. http://dx.doi.org/10.1007/s10295-005-0006-y.

Wang, M., Loccozia, J., Sun, L., Lin, C., Lin, Z., 2014. Inorganic-modified semiconductor $\mathrm{TiO}_{2}$ nanotube arrays for photocatalysis. Energy Environ. Sci. (7) 2182-2202. http://dx.doi.org/10.1039/c4ee00147h.

Wu, M.J., BAK, T., O'Doherty, P.J., Moffitt, M.C., Nowotny, J., Bailey, T.D., Kersaitis, C., 2014. Photocatalysis of titanium dioxide for water disinfection: challenges and future perspectives. Int. J. Photochem. 2014, 1-9. http://dx.doi.org/10.1155/ 2014/973484.

Wu, P., Xie, R., Shang, J.K., 2008. Enhanced visible-light photocatalytic disinfection of bacterial spores by palladium-modified nitrogen-doped titanium oxide. J. Am. Ceram. Soc. 91, 2957-2962. http://dx.doi.org/10.1111/j.15512916.2008.02573.x.

Wu, P., Xie, R., Imlay, J.A., Shang, J.K., 2009. Visible-light-induced photocatalytic inactivation of bacteria by composite photocatalysts of palladium oxide and nitrogen-doped titanium oxide. Appl. Catal. B 88 (3-4), 576-581. http:// dx.doi.org/10.1016/j.apcatb.2008.12.019.

Yagi, N., Mori, M., Hamamoto, A., Nakano, M., Akutagawa, M., Tachibana, S. Takahashi, A., Ikehara, T., Kinouchi, Y., 2007. Sterilization using 365 nm UV LED. In: Engineering in Medicine and Biology Society, 29th Annual International Conference of the IEEE, pp. 5842-5844. http://dx.doi.org/10.1109/ IEMBS.2007.4353676.

Yu, J.C., Yu, J., Ho, W., Jiang, Z., Zhang, L., 2002. Effects of F- doping on the photocatalytic activity and microstructures of nanocrystalline $\mathrm{TiO}_{2}$ powders. Chem. Mater. 14 (9), 3808-3816. http://dx.doi.org/10.1021/cm020027c.

Zhang, L., Yan, J., Zhou, M., Liu, Y., 2012. Photocatalytic inactivation of bacteria by $\mathrm{TiO}_{2}$-based compounds under simulated sunlight irradiation. Int. J. Mat. Sci. 2 (2), 43-46.

Zhang, Y., Collins, C., Graham, N., Templeton, M.R., Huang, J., Nieuwenhuijsen, M. 2010. Speciation and variation in the occurrence of haloacetic acids in three water supply systems in England. Water Environ. J. 24 (3), 237-245. http:/ dx.doi.org/10.1111/j.1747-6593.2009.00200.x. 